\title{
Some 1964 Bird Records for the Saskatoon District
}

by J. B. Gollop, Saskatoon

The following is a list of the more interesting bird observations made during 1964 in the Saskatoon district. The area included is a circle of approximately 30 -mile radius centering in the city-Townships 31 through 40 , Ranges I through 10, West of the Third Meridian.

Three species were particularly abundant at one time or another during the year. Short-eared Owls (Asio flammeus) were unusually common throughout the district beginning in late December, 1963. Several nests were found. This compares with one observation of a single bird in 1962 (Gollop, Roy, and Folker, 1963). An article by C. S. Houston in this issue on banding raptores refers to the influx of Long-eared Owls (Asio otus). On August 20 a southeastward migration of nighthawks (Chordeiles minor) was observed from 2202 York Avenue, Saskatoon. The flight was in progress when first noted, but 322 birds were counted between 6:18 and 7:30 p.m., C.S.T. (Michael A. Gollop).

First records of successful, unsuccessful and apparent breeding were received for four species. Ferruginous Hawk (Buteo regalis): A nest with four eggs was found on May 13 near Bradwell. Both birds were in attendance on May 30. The nest was empty and long deserted when checked on June 27 (C. S. Houston, Harold Moldenhauer, Ed Falk, Bill Horseman). Saw-whet Owl (Aegolius acadicus): three young were found in a nest. Red Crossbill (Loxia curvirostra): This species was recorded in or near Saskatoon from December, 1963, to July. Twenty-one individuals were banded in February, March and April in Mrs. Gordon Shepherd's yard. After nearly daily visits of banded birds from mid-March, a banded male and an unbanded female appeared on May 31 at Miss Marie Gillespie's feeding tray with a young bird, just able to fly. Other young appeared there in July. There is no doubt that these birds bred in Saskatoon (Houston). Virginia Rail (Rallus limicola): James A. Slimmon found two instances of probable breeding. On June 27 he found a nest with one egg believed to be this species two miles east of Saskatoon; no adults were seen. The nest was destroyed by July 2. On July 10 and 11 two Virginia Rails giving alarm notes followed Slimmon through part of the Hudson Bay Slough. This is the first July record in recent years for the district.

TV Tower kills: Prior to the 1964 southward migration, the largest kill recorded at CFQC-TV was 37 birds in 1963. From a migration that occurred during the night of August 21-22, 1964, 110 birds were picked up (M. A. Gollop and J. B. Gollop) and a migration on September 3-4 resulted in 191 dead birds (W. J. Maher, R. Busch, M. A. Gollop, J. B. Gollop). On nine more trips to October 10, a total of 37 birds was found. A separate article on these kills appears in this issue.

Three species were noted at unusual seasons: Hooded Merganser (Lophodytes cucullatus): two birds in female or immature plumage were studied on a slough north of the Saskatoon airport on June 28 (J. B. Gollop). Two Tree Sparrows (Spizella arborea) and one Harris' Sparrow (Zonotrichia querula) were recorded on January 4 in a sunflower patch southwest of the city (R. V. Folker, J. F. Roy).

The following are new records for the district, at least in recent years: Cinnamon Teal (Anas cyanoptera): one male was observed with $30 \mathrm{X}$ scope swimming and flying at Proctor Lake on May 17. Parasitic Jaeger (Stercorarius parasiticus): A single bird in light plumage was observed flying, sitting and standing for two periods totalling 22 minutes at Patience Lake on May 23. It came with 75 yards of two observers. At one point it chased and caught in its bill a small sandpiper; the "peep" escaped after the jaeger landed and attempted to transfer the bird from bill to feet. At the time, there were an estimated 17,000 shorebirds on Patience and Burke Lakes and a nearby slough (J. B. Gollop).

Partial albino birds were noted more frequently this year: Gadwall (Anas strepera): May 24 at Proctor Lake; one bird with overall pale buff plumage- 
not too unusual among Gadwall (J. B. Gollop). Widgeon (Mareca americana): May 18 north of Floral; one with tinges of yellow and darker flecks; it was with a flock of four other widgeon (M. A. Gollop). Stilt Sandpiper (Micropalama himantopus): on May 24 at Proctor Lake; one individual in a flock had a dirty white head and neck. Brewer's Blackbird (Euphagus cyanocephalus): on May 8 near CFQCTV tower; the female of a pair had one outer and one other tail feather pure white. There were three or four small spots of white on the bird's body. (J. B. Gollop.)

Other records: Horned Lark (Eremophila alpestris): A pair nested within the city limits in a newly planted lawn at 423 Quance Avenue. Three young were fledged. (J. F. Roy, R. V. Folker). Black-billed Magpie (Pica pica: a flock that centered its activities around a turkey farm just south of the city limits was checked almost weekly for four months. On August 1, there were at least 74 birds. The peak number was $114+$ on August 26. There were $93+$ on September 8 , $45+$ on October $17,42+$ on November 7 and $22+$ on November 22 , the last date that a count was made before the road became blocked with snow. Most satisfactory counts were made as the birds flew about a mile south of the farm to roost after sunset (J. B. Gollop). Lark Bunting (Calamospiza melanocorys): Since the birds reported by Roy (1960), which omitted a male near Bradwell (June 11, 1960), our records are as follows: 1961: four birds, south of Aberdeen and west of Vonda (May 21); 1962: none; 1963: 13 birds, Burke Lake (May 25 and June 2), Proctor Lake and Dundurn (June 16), Laura and Delisle (July 20), Dundurn (September 2); 1964: 3 individuals, Floral (May 18) and Hanley (June 21).

\section{LITERATURE CITED}

Gollop, J. B., J. F. Roy, and R. V. Folker. 1963. Some 1962 bird records for the Saskatoon district. Blue Jay, 21 (1): 12-13.

Roy, F. 1960. Birds of special interest in the Saskatoon area, Spring, 1960. Blue Jay, 18 (3): $117-118$.

\section{May Day Count, Saskatoon Natural History Society}

May 23, 1964: A species count within a circle centering on Saskatoon and having a radius of 25 miles. 5:00 a.m. to $8: 30$ p.m., CST. 20 observers in four parties. Temp. $70^{\circ}$, strong winds after 12 noon. Total, 129 species.

Of particular interest are the nesting record of the Ferruginous Hawk and the first Saskatoon record of the Parasitic Jaeger. The peak of the warbler migration occurred about a week prior to the count.

Common Loon, Red-necked Grebe, Horned Grebe, Eared Grebe, Western Grebe, Piedbilled Grebe, Great Blue Heron (nests with eggs), American Bittern, Canada Goose (pair with young at north end of Pike Lake), Mallard, Gadwall, Pintail, Green-winged Teal, Blue-winged Teal, American Widgeon, Shoveler, Redhead, Ring-necked Duck, Canvasback, Lesser Scaup, Common Goldeneye, Bufflehead, White-winged Scoter, Ruddy Duck, Sharp-shinned Hawk, Red-tailed Hawk, Swainson's Howk, Ferruginous Hawk (nest with eggs), Marsh Hawk, Pigeon Hawk, Sparrow Hawk, Ruffed Grouse, Sharp-tailed Grouse, Ring-necked Pheasant, Gray Partridge, Sora, American Coot, Semipalmated Plover, Killdeer, Golden Plover, Black-bellied Plover, Common Snipe, Upland Plover, Spotted Sandpiper, Willer, Lesser Yellowlegs, Pectoral Sand- piper, Baird's Sandpiper, Dowitcher (Longbilled?) Stilt Sandpiper, Semipalmated Sandpiper, Marbled Godwit, Sanderling, American Avocet, Wilson's.'Phalarope, Northern Phalarope, PARASITIC JAEGER (first Saskatoon record, B. Gollop), California Gull, Ring-billed Gull, Franklin's Gull, Common Tern, Black Tern, Rock Dove, Mourning Dove, Great Horned Owl, Burrowing Owl, Short-eared Owl, Belted Kingfisher, Yellowshafted Flicker, Yellow-bellied Sapsucker, Downy Woodpecker, Eastern Kingbird, Western Kingbird, Eastern Phoebe, Least Flycatcher, Horned Lark, Tree Swallow, Bank Swallow, Barn Swallow, Cliff Swallow, Blue Jay, Blackbilled Magpie, Common Crow, Black-capped Chickadee, House Wren, Long-billed Marsh Wren, Catbird, Brown Thrasher, Robin, Swainson's Thrush, Veery, Mountain Bluebird, Water Pipit, Sprague's Pipit, Loggerhead Shrike, Starling, Red-eyed Vireo, Philadelphia Vireo, Warbling Vireo, Tennessee Warbler, Yellow Warbler, Blackpoll Warbler, Ovenbird, Yellowthroat, American Redstart, House Sparrow, Bobolink, Western Meadowlark, Yellow-headed Blackbird, Red-winged Blackbird, Baltimore Oriole, Brewer's Blackbird. Common Grackle, Brown-headed Cowbird, Rosebreasted Grosbeak, Pine Siskin, American Goldfinch, Red Crossbill, Rufous-sided Towhee, Savannah Sparrow, Sharp-tailed Sporrow, Vesper Sparrow, Tree Sparrow (?), Chipping Sparrow, Clay-colored Sparrow, White-throated Sparrow, Song Sparrow, Lapland Longspur, Chestnut-collared Longspur. - Frank Roy, compiler. 